（40）経験的グリーン関数重ね合わせ法の工学的適用に関する検討

-1993年能登半島沖地震に対する適用性一

$\begin{array}{lrl}\text { 財団法人大阪土質試験所 } & \text { 正会員 } & \text { 鶴来雅人* } \\ \text { 財団法人大阪土質試験所 } & \text { 正会員 田居 優* } \\ \text { 京都大学防災研究所 } & \text { 入倉孝次郎** } \\ \text { 関西電力株式会社 } & \text { 岡崎 敦*** }\end{array}$

1 はじめに

経験的グリーン関数重ね合わせ法は小地震記録を用いて大地震時の地簏動を合成する方法であり，複雑な波動 伝播過程やサイト特性を直接見積る必要がないという点で非常に有効な方法である。また，この方法を用いた実地 震動の再現もこれまでにいくつかの地震で試みられ，その有効性が示されている。しかし，構造物の耐震設計用の 入力地震動策定にこの方法を用いる場合，いくつかの問題点が生じてくるものと思われる。そこで, 1993年能登半 島沖地震に適用することによって，本手法の工学的適用上の問題点の抽出とその解決方法の検討を行った。

\title{
2 解析概要
}

気象庁発表の1993年能登半島沖地震の概要を表 1 に示す。気象庁の観測網ではいくつかの余震記録が得られてい るが, 本解析では震源位置が本震のそれに最も近い2月16日に発生した余震記録をグリーン関数としてIRIKURAに よる手法”で重ね合わせを行った。検討した地点は輪島，金沢，富山，高田の 4 地点である。眓 1 に本震，余震 の震央位置および検討地点の位置を示す。図 2 には各地点での観測加速度波形（水平成分）を示す。

検討フローを図 3 に示す。検討方法はまず，震央に最も近い輪島での観測波と合成波とが最も良く一致する震源 パラメーターを見つけだし，その震源バラメーターに対して，輪島以外の 3 地点でシミュレーションし, 観測波と 比較するものである。なお, 断層の諸元は阿部らの検討 ${ }^{2)}$ より長さ $15 \mathrm{~km}$, 幅 $15 \mathrm{~km}$, 方位角 $\mathrm{N} 69^{\circ} \mathrm{E}$, 傾斜角 $42^{\circ}$ とした。また，重ね合わせ数は地震モーメントの比から $6^{3}$ とした。その地震モーメントの算出には佐藤によるマ グニチュードとの関係式゙)を用いた。この重ね合わせ数については，高周波数带域での本震と余震のフーリエス ペクトル比からも $6^{3}$ となる。

表 1 地震の概要

\begin{tabular}{|c|c|}
\hline 発生日時 & 1993 年2月7日22時27分44秒 \\
\hline マグニチュド & 6.6 \\
\hline 震央位置 & $37^{\circ} 39^{\prime} \mathrm{N}, 137^{\circ} 56^{\prime} \mathrm{E}$ \\
\hline 震源深さ & $25 \mathrm{~km}$ \\
\hline 各地の震度 & 輪島 $\cdots \mathrm{V} /$ 金沢，富山，上越 $\cdots \mathrm{IV}$ \\
\hline
\end{tabular}

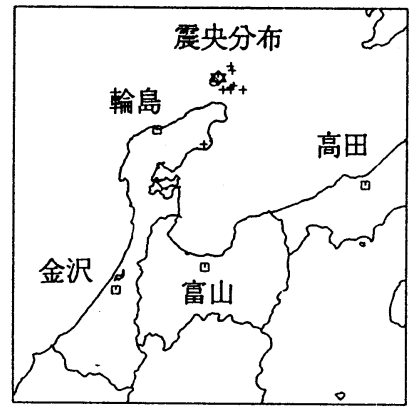

図 1 震央および観測箇所

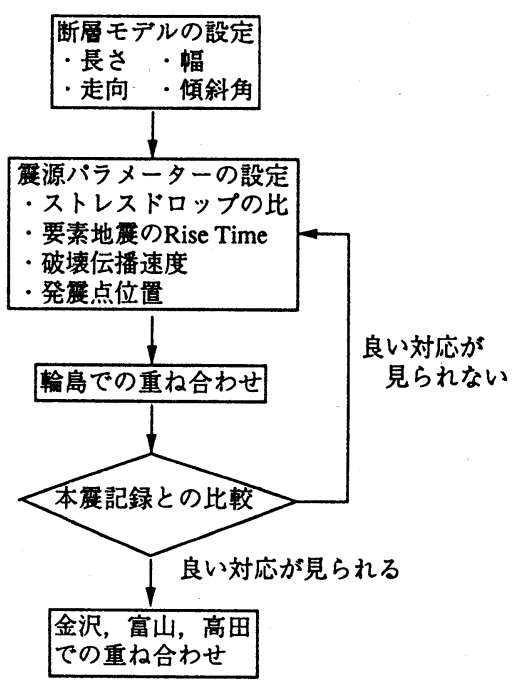

図 3 検討フロー 


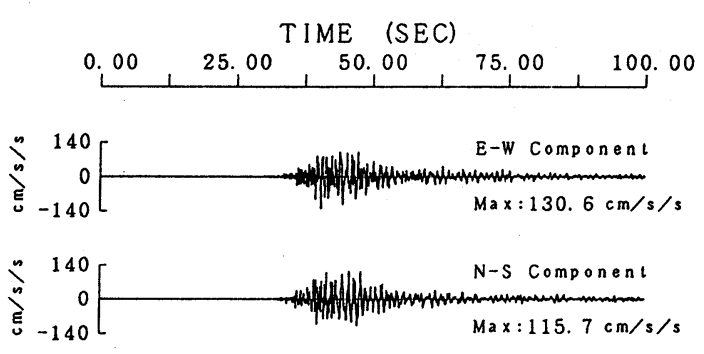

(1) 輪島

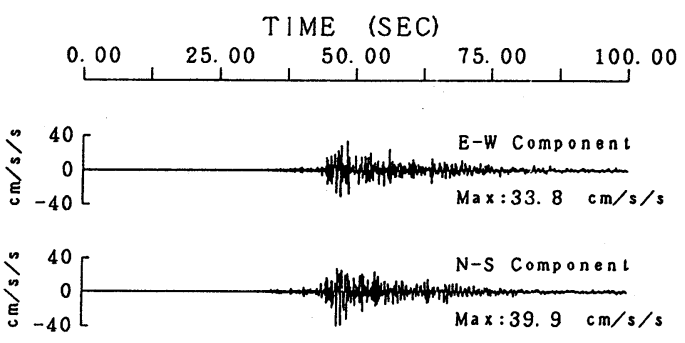

(3) 富山

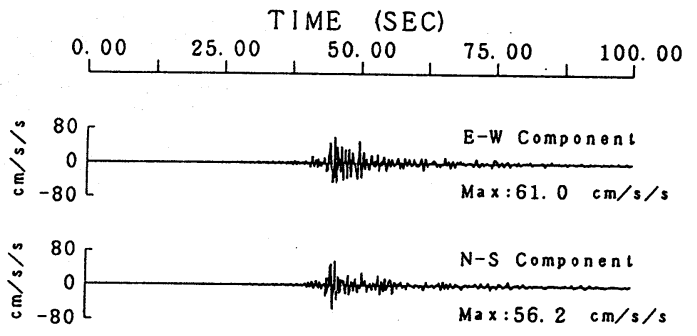

（2）金沢

TIME (SEC)

図 2 本震観测記録（加速度波形，水平成分）

\section{3 解析結果}

\section{1 問題点の抽出}

輪島での観測波と最も良く一致する合成波を与える震源 パラメーターを表 2 および図 4 に示す。このときの輪島, 金讯, 富山, 高田の各地点での観測加速度波形 (東西成分) を積分して得られる速度波形と合成波を図 5 に示す。

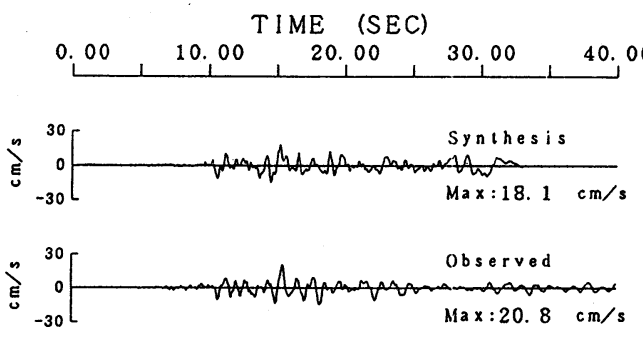

\section{（1）輪島}

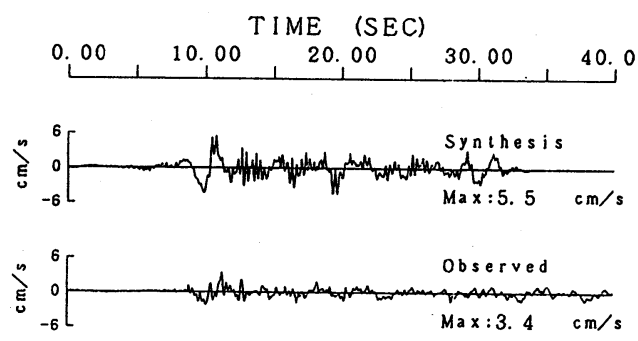

（3）富山
表 2 震源パラメーター

\begin{tabular}{|c|c|}
\hline 자자・ロップの比 & 3 \\
\hline 要素地震のRise Time & $0.1 \mathrm{sec}$ \\
\hline 再分割数 & 20 \\
\hline 破壊伝播速度 & $3 \mathrm{~km} / \mathrm{sec}$ \\
\hline 発震点（長さ方向） & 1 \\
\hline 発震点（幅方向） & 4 \\
\hline
\end{tabular}

長さ方向

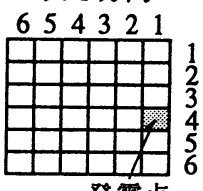

発震点

図4 発震点位置

TIME (SEC)

$0.00,10.00,20.00,30,00,40.00$
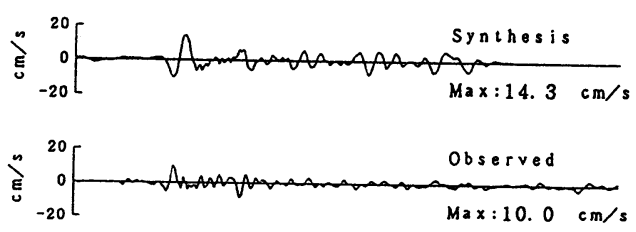

（2）金沢

TIME (SEC)
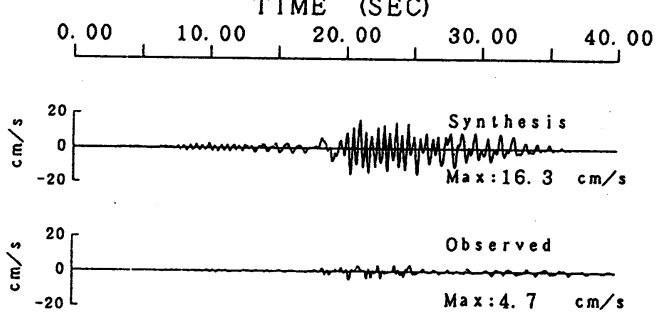

(4) 高田

図 5 観測波と合成波の比較 
まず，輪島では最大値，波形ともに良く一致している。次に，金沢や富山では波形は良く似ているが合成波の最 大值は観測波のそれの1.4倍，1.6倍となっている。さらに，高田では合成波の最大值は観測波のそれの3.5倍とかな ク大きな差が生じている。この原因は以下のように考えられる。図 6 に要素地震として用いた 2 月16日の余震の輪 島および高田での観測記録を示す。これより，高田での観測記録は輪島でのそれに比べて継続時間が非常に短く， 最大加速度も大きくなっていることがわかる。要素地震として用いた余震はマグニチュード5.0であり, このクラ スの地震は従来の検討で通常点震源として扱われていたものであるが，これらのことから勘案すると高田での観測 記録にはDirectivityの効果が多分に含まれている，すなわち高田が破壊の伝播方向に位置しているのではないかと 考えられる。

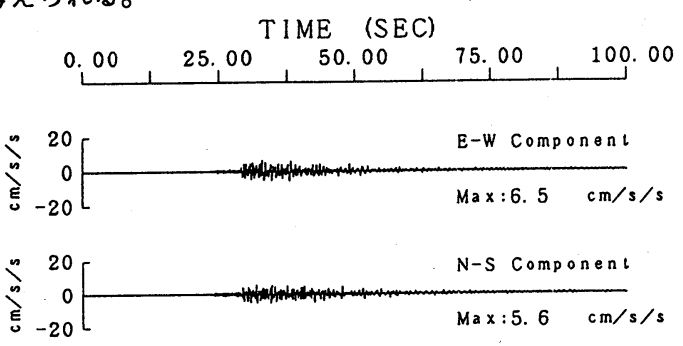

(1) 輪島

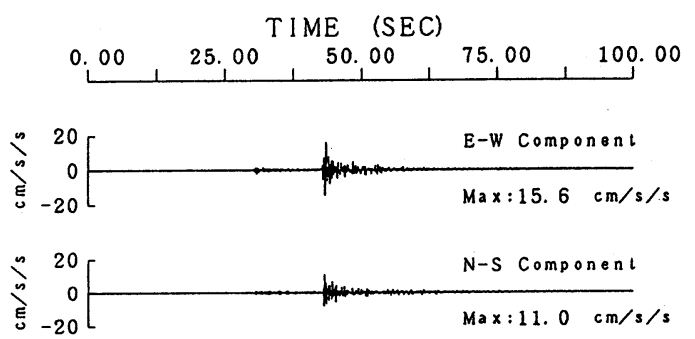

(2) 高田

図 62 月16日の余震観測記録（加速度波形, 水平成分）

\section{2 問題点の解決法}

前節で抽出された問題点を解決するため，以下に示す Ben-Menahemの移動震源による伝達関数 ${ }^{4)} に よ り$ 余震記録の Directivityを補正を行った。図 7 に補正方法の概念図を示す。

$$
\mathrm{Zc}=,(\sin \mathrm{Xc} / \mathrm{Xc})
$$

ここで, $\mathrm{Xc}=(\omega \mathrm{L} / 2 \mathrm{c})(\mathrm{c} / \mathrm{Vr})-\cos \theta\}, \mathrm{L}$ : 断層長さ, $\mathrm{c}$ : $\mathrm{S}$ 波速度, $\mathrm{V}_{\mathrm{r}}$ ：破壊伝播速度である。2 月16日の余震の場合 高田は $\theta=0^{\circ}$ の位置に相当し, 本震の場合は $\theta=90^{\circ}$ の位 置に相当するものと考えられる。そこで，それぞれの Z cの 比を本震観測記録のスペクトルに乗ずることによって記録の Directivityを補正した。観測余震記録（東西方向）と補正記 録の波形および変位フーリエスペクトルの比較を図 8 に示す。

TIME (SEC)

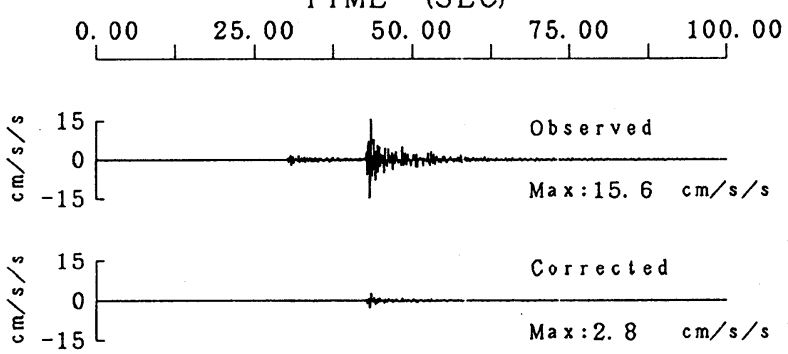

(上：観測記録, 下：補正記録)

（1）加速度波形

図 8 観測記録とDirectivityを補正した記録の比較
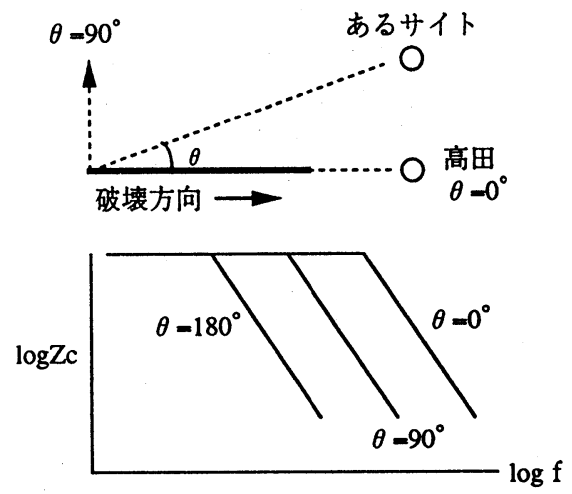

図 7 Directivityの補正方法の概念図

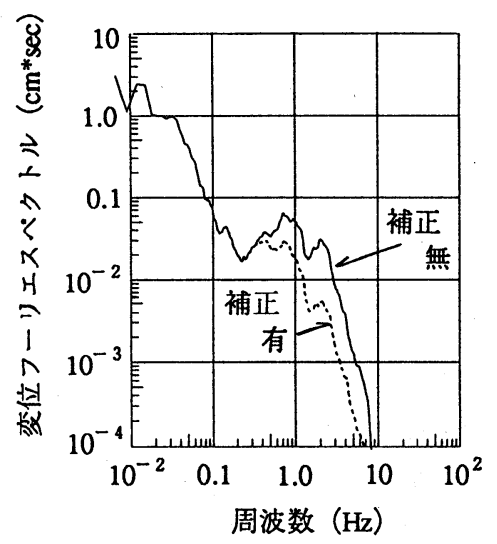

（2）変位フーリエスペクトル 


\section{3 再解析結果}

前節でDirectivityの補正をした波形をグリーン関数とし, 震源パラメーターを先の解析と全く同じ值（表 2）と して重ね合わせ手法を改めて適用した。高田での本震観測記録，2月16日の余震記録のDirectivityを補正せずに合成 した結果および補正をした後に合成した結果を図 9 に示す。Directivityを補正せずに合成した場合，最大速度値は 観測值の3.5倍程度であったが, Directivityの補正を行うことにより観測値とほほ同じ值が得られた。また図10に速 度応答スペクトル（減衰定数 $5 \%$ ）を示す。これより，全周期にわたって 4 倍程度の值であったが, Directivityの 補正を行うことにより周期 0.5 秒以上の周期では観測値とほほ一致した。

TIME (SEC)
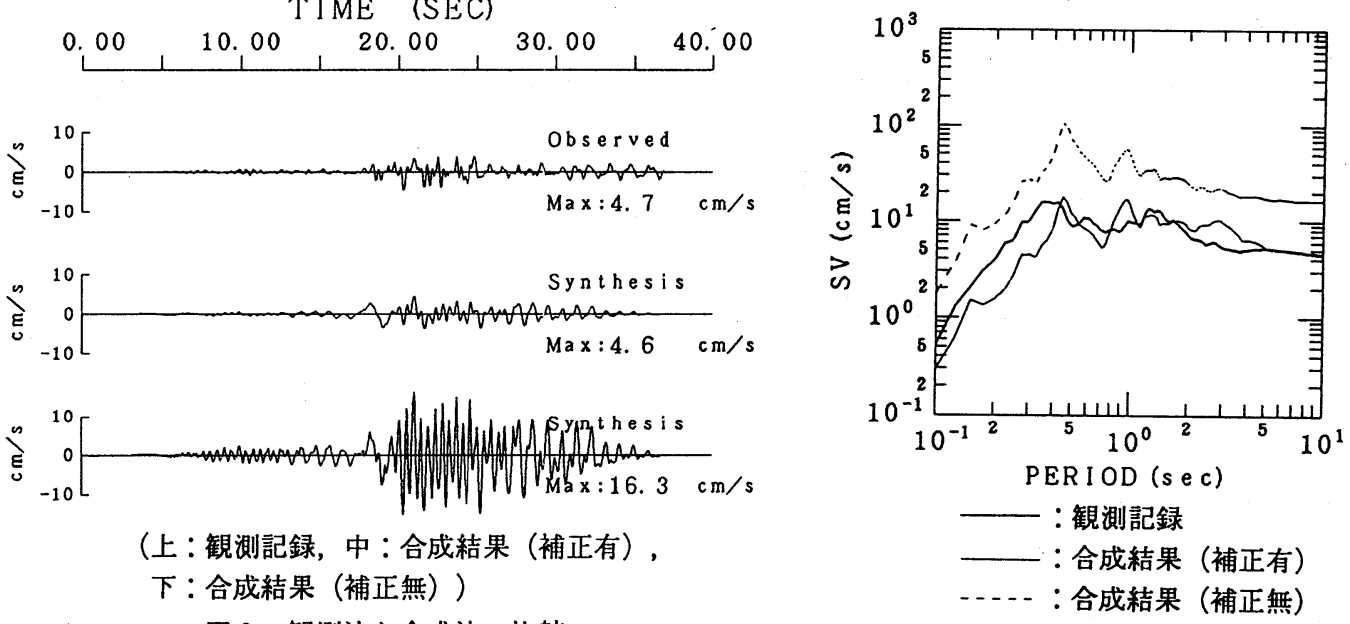

（上：観測記録，中：合成結果（補正有），

下: 合成結果 (補正無) )

図 9 観測波と合成波の比較

図10 速度応答スペクトルの比較

\section{4 おわりに}

本検討では, 経験的グリーン関数重权合わせ法を1993年能登半島沖地震に適用することによって, 同手法の工学 的適用上の問題点の抽出とその解決方法の検討を行った。その結果, 次の成果が得られた。

(1)従来から指摘されている通り，同手法は強震動予測に有効な手法である。

(2)工学的適用に際し，要素地震として用いた余震記録にDirectivity Effectの影響が強く含まれている場合，その合成

結果は本霞観測記録に比べ過大あるいは過小に評価するという問題点が生じる。

(3)(2)のうな問題点に対し，Directivity Effectの影響を除去することで本震観測記録と比較的対応の良い合成結果が 得られる。

(4)マグニチュード 5 程度の地震でもDirectivityの影響が生じ，点震源とは考えにくい場合があることを示唆される。

謝辞 本検討に用いた記録は気象庁87型電磁式強震計により得られたものです。記して感謝いたします。

\section{参考文献}

1) IRIKURA, K. : Prediction of Strong Acceleration Motion Using Empirical Green's Function, Proceedings of The Seventh Japan Earthquake Engineering Symposium, pp.151-156, 1986.

2 ）阿部, 岡田：能登半島沖地震の津波波源モデル, 日本地震学会1993年度秋季大会講演予稿集, p.171, 1993.

3 ）佐藤：日本の地震断層パラメター・ハンドブック, 鹿島出版会, 1989.

4 ) Ben-Menahem, A. : Radiation of seismic surface-waves from finite moving sources, Bulletin of The Seismological Society of America, Vol.51, pp.401-435, 1961.

$\begin{array}{llll}* & \text { 財団法人大阪土質試験所 } & (\overline{\mathrm{T}} 550 & \text { 大阪市西区西本町3-1-23） } \\ * * & \text { 京都大学防災研究所 } & (\bar{\tau} 611 & \text { 宇治市五ケ庄 }) \\ * * * & \text { 関西電力株式会社 } & (\bar{\tau} 530-70 & \text { 大阪市北区中之島3-3-22） }\end{array}$

